\title{
Relationship of Beet Curly Top Foliar Ratings to Sugar Beet Yield
}

Carl A. Strausbaugh and Anne M. Gillen, USDA-ARS NWISRL, 3793 North 3600 East, Kimberly, ID 83341; Stacey Camp, Amalgamated Sugar Co., 50 S. 500 W., Paul, ID 83347; Clinton C. Shock and Eric P. Eldredge, Oregon State University, Malheur Exp. Stn., 595 Onion Ave., Ontario, OR 97914; and John J. Gallian, University of Idaho, Research and Extension Center, Twin Falls 83303

\begin{abstract}
Strausbaugh, C. A., Gillen, A. M., Camp, S., Shock, C. C., Eldredge, E. P., and Gallian, J. J. 2007. Relationship of beet curly top foliar ratings to sugar beet yield. Plant Dis. 91:1459-1463.

Sugar beet (Beta vulgaris) varieties were evaluated for disease resistance to curly top to establish if disease ratings made in inoculated nurseries correlated with disease ratings and yield in sugar beet crops exposed to natural disease outbreaks. Cultivars were planted both in inoculated curly top nurseries in Kimberly, ID, and in commercial cultivar trials in irrigated fields near Ontario, OR and Nampa, ID. Plants were evaluated for curly top using a rating scale of 0 (no symptoms) to 9 (dead). Moderate disease pressure in the Ontario (mean rating $=3.8$ ) and Nampa (mean rating $=4.1$ ) fields resulted in significant differences for disease rating, root yield, sugar content, and estimated recoverable sugar among cultivars. Disease ratings from both commercial fields were positively correlated $(r=0.91$ and $0.82, P<0.0001)$ with ratings from the inoculated nurseries. In commercial fields, root yield was negatively related to disease rating $\left(r^{2}=0.47\right.$ and $0.39, P \leq 0.0004)$. For each unit increase in disease rating (increasing susceptibility), root yield decreased 5.76 to 6.93 t/ha. Thus, curly top nurseries reliably predict curly top resistant cultivars for commercial cultivation.
\end{abstract}

Additional keywords: BCTV, beet leafhopper, BMCTV, BSCTV, Circulifer tenellus, Curtovirus, geminivirus

Curly top of sugar beets (Beta vulgaris L.) is caused by Beet curly top virus (BCTV), a monopartite geminivirus and the type member of the genus Curtovirus within the family Geminiviridae (14,21). BCTV exists as three strains, designated $\mathrm{CFH}$, Worland, and $\mathrm{Cal} / \mathrm{Logan}$, which vary for severity on sugar beet (15-17). More recently, sequence data have been used to designate these strains as separate species with the names Beet severe curly top virus (BSCTV, formerly CFH), Beet mild curly top virus (BMCTV, formerly Worland), and BCTV (formerly Cal/Logan) (14).

Curly top can cause severe and widespread losses of sugar beet, tomato, bean, cucurbits, and many other hosts (2). Curly top is endemic in arid and semiarid areas of the western United States, southwestern Canada, Mexico, the Mediterranean Basin, Turkey, and Iran (2). Severe losses of sugar beet to curly top were first noted in Utah and California in the late 1890s (2). In southern Idaho, curly top first became a

Corresponding author: Carl A. Strausbaugh

E-mail: carls@nwisrl.ars.usda.gov

Accepted for publication 18 June 2007.

doi:10.1094/PDIS-91-11-1459

This article is in the public domain and not copyrightable. It may be freely reprinted with customary crediting of the source. The American Phytopathological Society, 2007. serious threat to sugar beet production in 1919 (2). By the time resistant cultivars became available in the mid-1930s, curly top had almost eliminated the sugar beet industry in the western United States (2). In California and Wyoming, curly top management programs based on the migratory behavior of the beet leafhopper, Circulifer tenellus (Baker), from noncrop areas are utilized in control efforts $(19,23)$. These programs are based on aerial applications of insecticides in noncrop areas where the insect vector tends to congregate. However, as increasing urbanization occurs near farming areas, many areas are no longer accessible to spraying, and nontarget organisms influenced by the sprays make aspects of these programs undesirable (23). Today curly top is largely managed through the use of resistant varieties (20). Early plantings and the use of systemic insecticides (phorate, aldicarb, imidacloprid, and clothianidin) also help limit curly top or delay the onset of symptoms $(2,3,9,11,12,19,23)$.

Curly top viruses are transmitted by the beet leafhopper and overwinter in host plants or adult female leafhoppers that survive on mustard species (2). Even the coldest southern Idaho winters will not eliminate beet leafhoppers (2). Eggs are laid on leaves and stems in the spring, leading to three or more leafhopper generations per year. The first generation occurs on winter annual mustards prior to spring migration. The second and third generations occur on sugar beets and other hosts. Generation development takes 1 to 2 months depending on temperature (2). Beet leafhoppers can survive on plants belonging to 19 families and 106 species, and curly top is known to occur in more than 300 species in 44 plant families $(2,6)$. Beet leafhoppers acquire BCTV by feeding on infected plants, and the percentage of a population that acquires and transmits the virus increases as feeding time increases (2). In sugar beet, symptoms begin to appear as vein clearing in young leaves within 2 to 10 days of infection (2). As the disease progresses, leaves become dwarfed, crinkled, and roll upward and inward. Leaves that are mature at the time of infection do not usually show symptoms. The severity of symptoms varies with the earliness of infection, susceptibility of the cultivar, virulence of the virus strain, and temperature $(2,24)$. Plants of susceptible cultivars infected as seedlings or young plants may die.

Resistance to curly top virus strains is quantitatively inherited, making it difficult to maintain high levels of resistance in the parental lines used to produce commercial cultivars (9). When resistance to rhizomania, caused by Beet necrotic yellow vein virus, was rapidly incorporated into commercial cultivars, maintaining resistance to curly top was difficult (9). Also, some of the sugar beet cultivars with the highest yield potential lack good curly top resistance (9). Therefore, efforts continue to evaluate sugar beet cultivars and germplasm annually to improve resistance to curly top while enhancing yield. Recently, a rapid greenhouse assay was shown to be effective in selecting resistant cultivars and provided evidence that resistance was associated with lower virus concentration and was not just tolerance (24).

To identify sugar beet cultivars with resistance to strains of curly top viruses, trials in late planted inoculated nurseries are conducted annually in Idaho based on the methods published in 1974 (10). Plants in these nurseries are only evaluated visually for foliar symptoms, and yields are not assessed. Thus, studies were conducted to assess whether the curly top disease ratings made under inoculated conditions in these curly top nurseries correlate with disease ratings and yield measured under commercial sugar beet production conditions in 
similar growing areas. Preliminary reports have been published $(5,20)$.

\section{MATERIALS AND METHODS}

Nampa trial and corresponding curly top nursery. A trial with 29 commercial sugar beet cultivars was planted on 19 March 2004 in a commercial sprinklerirrigated field near Nampa, ID. The field trial was in an area where curly top had been a problem in previous years, and plants became naturally infected with curly top. The plots were planted at a density of
469,500 seeds/ha and thinned to 88,000 plants/ha. Plots were four rows wide (0.56-m row spacing) and $10.97 \mathrm{~m}$ long. The experimental design was a randomized complete block with eight replications. The crop was managed by the grower using standard cultural practices. Symptoms of curly top began appearing in late May (8 to 9 weeks after planting). The disease ratings were recorded for the plants in each plot on 14 September by three observers using a rating scale of 0 to 9 (Table 1). The center two rows were

Table 1. Beet curly top disease rating system utilized by the Beet Sugar Development Foundation

\begin{tabular}{|c|c|}
\hline Rating & Description of plant symptoms ${ }^{\mathrm{z}}$ \\
\hline 0 & Healthy; no symptoms \\
\hline 1 & Vein clearing of heart leaves, slight pimpling of veins on the underside of leaves \\
\hline 2 & $\begin{array}{l}\text { Slight leaf curl of the edges of new leaves; pimpling on the veins of the underside of the } \\
\text { leaves }\end{array}$ \\
\hline 3 & Center few whorls of leaves with curling edges \\
\hline 4 & Most leaves moderately curling; more than half of the upper surface of the leaf still visible \\
\hline 5 & $\begin{array}{l}\text { Slight stunting, severe leaf curling; less than half of the upper leaf surface visible due to } \\
\text { curling; most of the larger leaves still erect }\end{array}$ \\
\hline 6 & Stunting, slight yellowing; most leaves becoming prostrate \\
\hline 7 & Severe stunting, yellowing; leaves prostrate and some leaves dead \\
\hline 8 & Only the center few whorls of leaves green and alive \\
\hline 9 & Plant dead \\
\hline
\end{tabular}

${ }^{\mathrm{z}}$ Rating system published by David Mumford in 1974 (10).

Table 2. Root and sugar yield and beet curly top disease index ratings from the 2004 commercial sugar beet production trial, Nampa, ID

\begin{tabular}{|c|c|c|c|c|}
\hline Commercial cultivars & Disease rating $^{\mathbf{y}}$ & $\begin{array}{c}\text { Root yield } \\
\text { (t/ha) }\end{array}$ & $\begin{array}{c}\text { Sugar content } \\
(\%)\end{array}$ & $\begin{array}{c}\text { Sugar yield } \\
(\mathrm{kg} / \mathrm{ha})\end{array}$ \\
\hline Beta 8600 & $3.88 \mathrm{hi}$ & $110.0 \mathrm{a}$ & 16.24 bcde & $13,825 \mathrm{a}$ \\
\hline HM Alliance & $3.42 \mathrm{jk}$ & $105.9 \mathrm{abc}$ & $16.20 \mathrm{bcdefg}$ & $13,378 \mathrm{ab}$ \\
\hline HM Oasis & $3.00 \mathrm{mn}$ & $107.4 \mathrm{ab}$ & 16.03 defghi & $13,334 \mathrm{ab}$ \\
\hline Beta $4490 \mathrm{R}$ & $4.24 \mathrm{efg}$ & 101.9 bcdef & $16.69 \mathrm{a}$ & $13,199 \mathrm{abc}$ \\
\hline HM 2986 RZ & $3.33 \mathrm{kl}$ & $105.9 a b c$ & 16.01 defghi & 13,165 abcd \\
\hline SX Cascade & $3.08 \mathrm{lmn}$ & $104.4 \mathrm{abcd}$ & $16.20 \mathrm{bcdefg}$ & $13,155 \mathrm{abcd}$ \\
\hline HH Acclaim R & $3.67 \mathrm{ij}$ & $107.5 \mathrm{ab}$ & 15.85 fghij & 13,058 bcde \\
\hline HM PM21 & $2.83 n$ & $100.7 \mathrm{cdefg}$ & $16.46 \mathrm{ab}$ & $12,864 \mathrm{bcdef}$ \\
\hline HM 2980 RZ & $3.88 \mathrm{hi}$ & 104.8 abcd & 15.84 fghij & 12,827 bcdef \\
\hline Beta $4199 \mathrm{R}$ & $4.09 \mathrm{gh}$ & 99.4 defgh & $16.42 \mathrm{abc}$ & $12,680 \mathrm{bcdef}$ \\
\hline SX Puma & $3.21 \mathrm{klm}$ & 100.9 cdefg & 16.07 cdefgh & 12,590 cdefg \\
\hline Crystal 217 R & $5.16 \mathrm{bc}$ & 103.3 bcde & $15.77 \mathrm{hij}$ & 12,483 cdefgh \\
\hline HH Meridian R & $3.79 \mathrm{i}$ & 103.2 bcde & $15.67 \mathrm{ji}$ & 12,469 cdefgh \\
\hline HM Owyhee & $2.95 \mathrm{mn}$ & 98.9 defgh & $16.20 \mathrm{bcdefg}$ & 12,443 defgh \\
\hline HM 2984 RZ & $3.46 \mathrm{jk}$ & $100.8 \mathrm{cdefg}$ & 15.82 ghij & 12,405 efgh \\
\hline ACH Mustang & $3.92 \mathrm{hi}$ & 100.9 cdefg & 15.92 defghij & $12,325 \mathrm{fghi}$ \\
\hline Beta $8220 \mathrm{~B}$ & $4.08 \mathrm{gh}$ & 99.7 defgh & 16.03 defghi & 12,308 fghi \\
\hline HH Phoenix R & $4.42 \mathrm{def}$ & $101.6 \mathrm{bcdef}$ & $15.58 \mathrm{jk}$ & 12,274 fghi \\
\hline HM 1642 & $4.58 \mathrm{~d}$ & 94.5 hijk & $16.51 \mathrm{ab}$ & 12,174 fghij \\
\hline Crystal 333 R & $5.29 \mathrm{~b}$ & 97.2 fghi & 15.97 defghi & 11,912 ghijk \\
\hline HM 2989 RZ & $4.33 \mathrm{defg}$ & 94.9 ghij & 16.23 bcdef & 11,898 ghijk \\
\hline HH Eagle R & $4.50 \mathrm{de}$ & $98.1 \mathrm{efgh}$ & $15.55 \mathrm{kj}$ & 11,824 hijkl \\
\hline HM 2988 RZ & $4.50 \mathrm{de}$ & $91.4 \mathrm{ijk}$ & $16.28 \mathrm{bcd}$ & $11,609 \mathrm{ijkl}$ \\
\hline SX Raptor RZ & $5.00 \mathrm{c}$ & 93.8 hijk & $15.77 \mathrm{hij}$ & $11,462 \mathrm{jklm}$ \\
\hline Beta $4035 \mathrm{R}$ & $4.21 \mathrm{fg}$ & 95.9 fghij & $15.28 \mathrm{k}$ & $11,304 \mathrm{klm}$ \\
\hline Beta 4773 R & $5.14 \mathrm{bc}$ & $90.7 \mathrm{jk}$ & 15.91 defghij & $11,136 \mathrm{~lm}$ \\
\hline HH 142 R & $4.58 \mathrm{~d}$ & $88.7 \mathrm{k}$ & 15.87 efghij & $10,824 \mathrm{~m}$ \\
\hline Crystal 9906 R & $5.00 \mathrm{c}$ & $88.7 \mathrm{k}$ & $15.56 \mathrm{kj}$ & $10,754 \mathrm{~m}$ \\
\hline Beta $4614 \mathrm{R}$ & $5.92 \mathrm{a}$ & 82.11 & 14.171 & $8,995 \mathrm{n}$ \\
\hline Overall mean & 4.11 & 99.1 & 15.93 & 12,230 \\
\hline Coefficient of variation & 6.7 & 6.1 & 2.5 & 6.1 \\
\hline$P>\mathrm{F}^{\mathrm{z}}$ & $<0.0001$ & $<0.0001$ & $<0.0001$ & $<0.0001$ \\
\hline $\operatorname{LSD}(P \leq 0.05)$ & 0.27 & 6.0 & 0.39 & 731 \\
\hline
\end{tabular}

${ }^{y}$ Disease ratings were analyzed using the mean score for each plot (three ratings per plot). The disease rating scale ranged from 0 (no symptoms) to 9 (dead plant).

${ }^{\text {z }} P>F$ was the probability associated with the $F$ value in the analysis of variance. LSD $=$ Fisher's protected least significant difference. Means followed by the same letter within a column did not differ significantly based on Fisher's protected LSD with $P \leq 0.05$.

harvested on 20 October using a small plot harvester.

The 2004 curly top nursery was conducted in a commercial field near Kimberly, ID with the same cultivars as the Nampa trial. Plots two rows wide (0.56-m row spacing) and $2.74 \mathrm{~m}$ long were planted on 7 June 2004. The sugar beet seed was planted at a density of 350,900 seeds/ha and thinned to 88,100 plants/ha. The experimental design was a randomized complete block with three replications. The field had been fumigated with Telone II (94\% 1,3 dichloropropene; Dow AgroSciences LLC, Indianapolis, IN) at 187 liters/ha on 3 May, and then disked to seal the soil. Fertilization and weed control practices were consistent with commercial production practices. The trial was initially irrigated with solid set sprinklers until 26 June, and then switched to furrow irrigation. Viruliferous beet leafhoppers (1.5 hoppers/plant) raised in a greenhouse on infected plants were applied on 13 July. For 1 week, the leafhoppers were moved three times daily (daybreak, midday, and sundown) by dragging a tarp over the plants to encourage leafhopper movement and uniform plant infection. The field was sprayed with the insecticide Lorsban $4 \mathrm{E}$ (44.9\% chlorpyrifos; Dow AgroSciences LLC) on 4 August at 1.75 liters/ha to kill the beet leafhoppers. The disease ratings were recorded for the plants in every plot on 13 September by the same three raters using the same rating system as in the cultivar trial.

Malheur County trial and corresponding curly top nursery. A trial with 26 commercial sugar beet cultivars was planted on 6 April 2005 in a furrowirrigated field near Ontario, OR in an area where curly top had been a problem in previous years. Plants became naturally infected with curly top. Sugar beet seed was planted at a density of 704,500 seeds/ha and thinned to 100,600 plants/ha. Plots were four rows wide $(0.56-\mathrm{m}$ row spacing) and $7.01 \mathrm{~m}$ long. The experimental design was a randomized complete block with eight replications. The crop was managed using standard cultural practices (13). Curly top symptoms began appearing in late May (7 weeks after planting). The disease data were recorded for the plants in every plot on 16 September by the same three observers using the same disease rating system as in the previous trials (Table 1). The center two rows were harvested on 13 and 14 October using a small plot harvester.

The 2005 curly top nursery was conducted in a commercial field near Kimberly, ID with the same cultivars as the Malheur County trial. The nursery design and cultural practices were the same as those described for the 2004 nursery, except the field was fumigated on 14 April, planting occurred on 20 June, six replications were used, viruliferous leafhoppers 
were released on 25 July, and disease data were recorded on 12 September.

Sugar analysis. Sugar content of the beets was determined by the Amalgamated Sugar Co. laboratory using an Autopol 880 polarimeter (Rudolph Research Analytical, Hackettstown, NJ) and a half-normal weight sample dilution and aluminum sulfate clarification method generally described in ICUMSA Method GS6-3 [1994] (1). Recoverable sugar was estimated based on root yield, percent sugar, and conductivity. Conductivity was measured using a Model 875EC conductivity probe (Foxboro, Foxboro, MA).

Data analysis. The three disease ratings per plot were averaged prior to analysis. Disease and plant performance data were analyzed in SAS (SAS Institute Inc., Cary, $\mathrm{NC})$ using the general linear models procedure (Proc GLM), and Fisher's protected least significant difference was used for mean comparisons. Correlations based on Spearman's coefficient of rank correlation and linear regression analyses (Proc reg) were conducted in SAS.

\section{RESULTS}

In the Nampa trial, yields were above average for this growing area and the natural disease pressure was uniform and moderately severe (Table 2). Cultivar response to curly top ranged from commercially acceptable (slight leaf curl to moderate curling on most leaves) to moderately affected (larger leaves becoming prostrate). There were significant differences among commercial cultivars for disease rating, root yield, sugar content, and sugar yield (Table 2). Disease ratings from cultivars in the commercial production trial were positively correlated $(r=0.91, P<0.0001)$ with those from the 2004 curly top nursery in Kimberly, ID (Fig. 1A). The regression for sugar yield versus disease rating indicated that sugar yield was negatively related to disease rating $\left(r^{2}=0.54, P<\right.$ $0.0001)$. For each unit increase in disease rating there was a decrease in sugar yield of $943 \mathrm{~kg} / \mathrm{ha}$. The regression of root yield versus disease rating (Fig. 2A) was also a negative relationship $\left(r^{2}=0.47, P<\right.$ $0.0001)$. There was a decrease in root yield of $5.67 \mathrm{t} / \mathrm{ha}$ for every unit increase in disease rating.

In the Malheur trial, yields were typical for this site and above average for growers in this region. Natural disease pressure was uniform and moderately severe (Table 3 ). Cultivar response to curly top ranged from acceptable (slight leaf curl to moderate curling on most leaves) to moderately affected (larger leaves becoming prostrate). There were significant differences among cultivars for disease rating, root yield, sugar content, and sugar yield (Table 3). Disease ratings for cultivars in the commercial production trial were positively correlated $(r=0.82, P<0.0001)$ with those from the 2005 curly top nursery in
Kimberly, ID (Fig. 1B). The regression for sugar yield versus disease rating indicated that yield was negatively related to disease rating $\left(r^{2}=0.36, P=0.0007\right)$. For each unit increase in disease rating, there was an average decrease in sugar yield of 862 $\mathrm{kg} / \mathrm{ha}$. The regression of root yield versus disease rating (Fig. 2B) was also negative $\left(r^{2}=0.39, P=0.0004\right)$. There was a decrease in root yield of $6.93 \mathrm{t} / \mathrm{ha}$ for every unit increase in disease rating.

\section{DISCUSSION}

Data show that inoculated curly top nurseries can be used to identify cultivars that develop fewer foliar symptoms and consequently less yield reduction in naturally infected commercial fields. The correlations between yield in commercial fields and disease ratings were highly significant in both years. Regression analyses indicated that disease ratings in trials in commercial fields explained a significant portion of the variation in root yield and recoverable sugar under moderate disease pressure. Root yield declined 5.8 and 6.9 t/ha per unit increase in disease rating under natural conditions in commercial fields. Previous reports in Idaho and California under severe (widespread symptoms in early May or before) curly top conditions found a 13.0 and $9.1 \mathrm{t} / \mathrm{ha}$ decline in root yield per unit increase in disease rating, respectively $(8,9)$, which is consistent with the findings in this report.

In contrast to the previous Idaho (8) and California (9) reports, this study involved numerous sugar beet cultivars with varying levels of curly top resistance evaluated over more than 1 year. Even though the severity of curly top in the nursery was higher than that based on natural infection in the field, there was a close relationship between foliar disease ratings in the nursery and commercial fields. Therefore, the nursery data can be used to select for
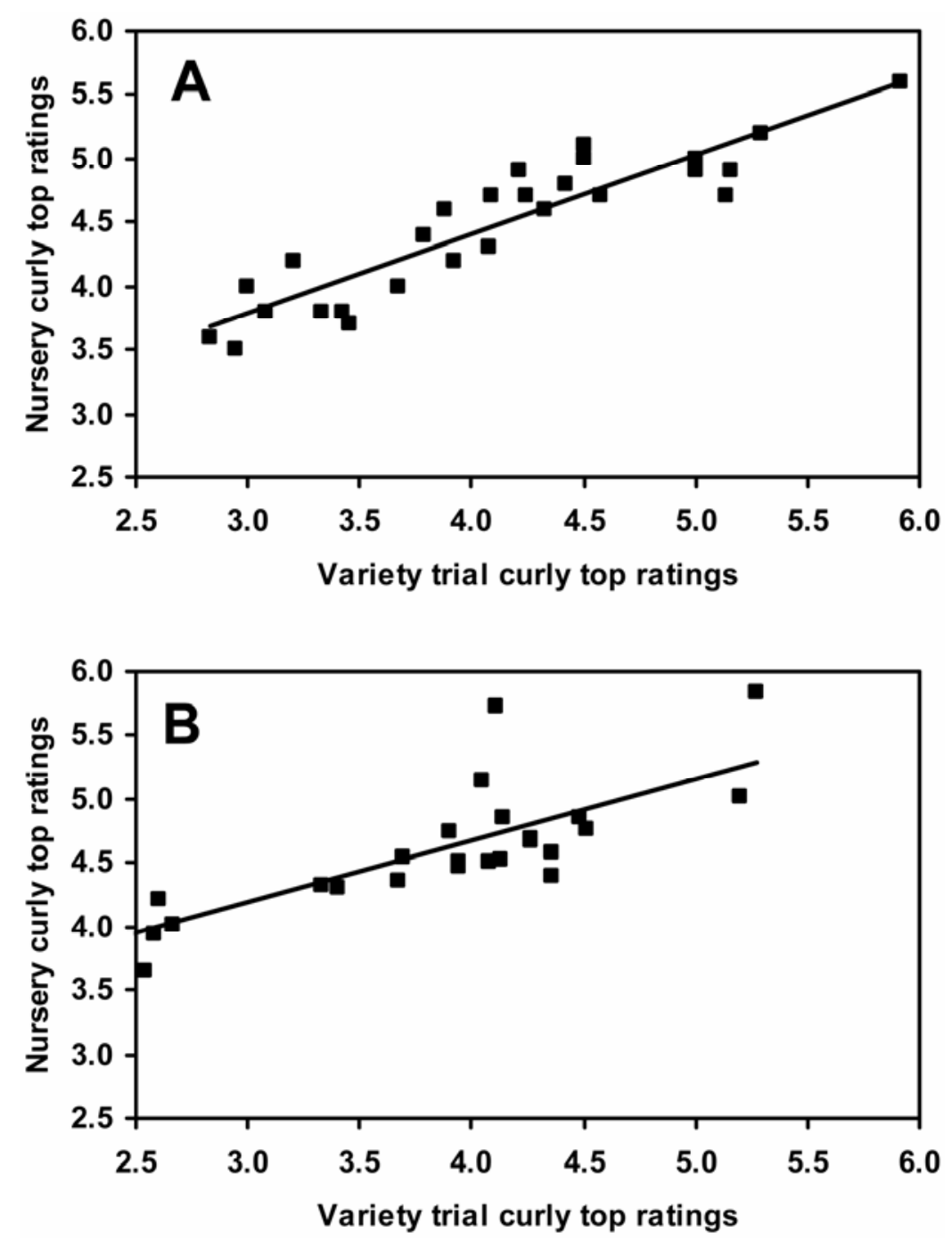

Fig. 1. Relationship between curly top disease ratings in the curly top nursery at Kimberly, ID and sugar beet cultivar trials at Nampa, ID in 2004 (A) and Ontario, OR in 2005 (B). Plants were evaluated for curly top symptoms using a disease rating scale of 0 (no symptoms) to 9 (dead). Observations from three raters were averaged to establish mean disease ratings. Based on Spearman's coefficient of rank correlation, disease ratings were positively correlated $(r=0.91$ and $0.82, P<0.0001$ for panels $\mathbf{A}$ and B, respectively). 

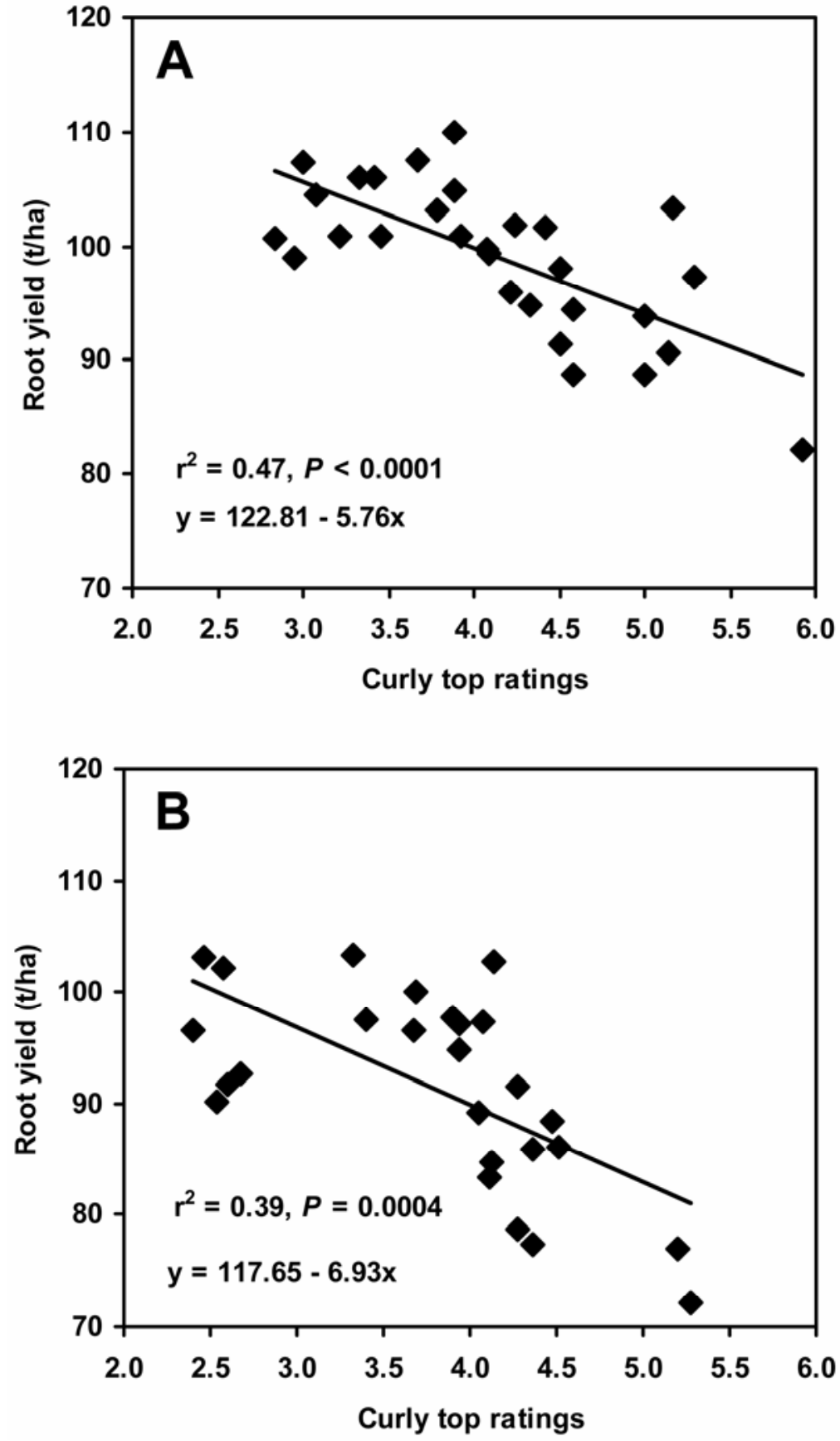

Fig. 2. Relationship between curly top disease ratings and root yield in sugar beet cultivar trials at Nampa, ID in 2004 (A) and Ontario, OR in 2005 (B). Plants were evaluated for curly top symptoms using a disease rating scale of 0 (no symptoms) to 9 (dead). Observations from three raters were averaged to establish mean disease ratings.

commercial cultivars with fewer foliar symptoms. However, the nursery does not select for yield. The relationship between disease ratings and yield in commercial fields was significant, but left a considerable portion of the variation unexplained. Since some cultivars with more foliar symptoms may out yield more resistant cultivars, yield potential must depend upon environmentally influenced genetic factors other than resistance. Yield potential will have to be determined independent of the curly top nursery because the number of entries does not allow for yield assessment.
In the 1950s, with resistant cultivars and only mild strains of the virus present, the prevention of early infection was assumed to be less urgent than in the 1970s (7). During the 1960s and 1970s, the virus increased in severity and the observation that resistant plants infected 4 to 5 weeks after planting would not sustain damage was no longer true (7). Plants of resistant cultivars infected even 10 weeks after planting could sustain yield losses over $13 \%$ (7). Thus, the authors suggested that a reasonable estimate of sugar beet yield loss due to severe curly top virus infection could be derived from regression analysis of foliar symptoms versus sugar beet yield. These suggestions have been confirmed by the current data even though only moderate levels of curly top were present. If conditions had been more severe as occurred in 1992 in southern Idaho, a higher percentage of variation could likely have been explained by the regression analyses. Fortunately, severe conditions occur very sporadically in the western United States. Therefore, these data based only on moderate curly top pressure may be more indicative of losses growers experience on a frequent basis.

Curly top can be caused by any one of three virus species (BSCTV, BMCTV, and BCTV). BSCTV, formerly known as CFH strains, causes more severe symptoms than BCTV, formerly known as Cal/Logan strain, in most hosts $(15,16)$. A series of chimeric virus genomes derived from BSCTV and BCTV (Logan strain) produced a variety of symptom types, including both the parental and novel symptom phenotypes (16), suggesting that multiple viral genetic determinants influenced the type of symptoms produced (22). A study of curly top species in the western United States in 1994 and 1995 indicated that BSCTV and BMCTV (formerly the Worland strain) were the primary species (17). In the Stenger and McMahon study (17), BSCTV was the only species detected in commercial fields in Idaho. A survey in 2006 revealed that BSCTV and BMCTV were present throughout southern Idaho, but BCTV had only a limited distribution (C. A. Strausbaugh, unpublished data). In the past, both BCTV and BSCTV have been recovered from the curly top nursery in Idaho (18), but in 2006 all three species were present (C. A. Strausbaugh, unpublished data). The feed beets used to render the leafhoppers viruliferous for the 2006 nursery were from the 2005 curly top nursery. Thus, all three species were likely present in the 2005 nursery, since there was little natural curly top disease present in the Kimberly, ID area in 2006.

Resistance for curly top is a quantitatively inherited trait, which makes it difficult to breed and maintain adequate levels of resistance in commercial cultivars (9). Most modern commercial cultivars are hybrids derived from three parental lines: a multigerm pollen parent, a monogerm $F_{1}$ hybrid seed-bearing parent that is derived from a cytoplasmic male-sterile inbred line, and a type $\mathrm{O}$ inbred line that preserves cytoplasmic male sterility in the seed-bearing parent (4). To maintain acceptable curly top resistance in commercial cultivars, all three parental lines should contain adequate levels of resistance.

With the addition of resistance to strains of Beet necrotic yellow vein virus as a priority in sugar beet breeding programs, along with the transition to transgenic sugar beets, maintaining levels of curly top 
Table 3. Root and sugar yield and beet curly top disease index ratings from the 2005 commercial sugar beet production trial at the Oregon State University Malheur Experiment Station, Ontario, OR

\begin{tabular}{|c|c|c|c|c|}
\hline Commercial cultivars & Disease ratingy & $\begin{array}{c}\text { Root yield } \\
\text { (t/ha) }\end{array}$ & $\begin{array}{c}\text { Sugar content } \\
(\%)\end{array}$ & $\begin{array}{l}\text { Sugar yield } \\
\text { (kg/ha) }\end{array}$ \\
\hline HM 2992 RZ & $4.14 \mathrm{~cd}$ & $102.7 \mathrm{ab}$ & $16.84 \mathrm{cdef}$ & $13,151 \mathrm{a}$ \\
\hline HM РM90 & $2.58 \mathrm{~h}$ & $102.2 \mathrm{ab}$ & 16.97 bcde & $13,123 \mathrm{a}$ \\
\hline Beta 8600 & $3.33 \mathrm{~g}$ & $103.3 \mathrm{a}$ & 16.84 cdef & $13,088 \mathrm{a}$ \\
\hline SX Cascade & $2.46 \mathrm{~h}$ & $103.1 \mathrm{a}$ & 16.80 cdefg & $13,072 \mathrm{a}$ \\
\hline Beta $4490 \mathrm{R}$ & $3.90 \mathrm{de}$ & 97.7 abcd & $17.21 \mathrm{ab}$ & $12,686 \mathrm{ab}$ \\
\hline Beta $4199 \mathrm{R}$ & $3.94 \mathrm{de}$ & 97.1 abcde & $17.33 \mathrm{a}$ & $12,633 \mathrm{ab}$ \\
\hline Crystal $316 \mathrm{R}$ & $3.69 \mathrm{ef}$ & $100.0 \mathrm{abc}$ & 16.75 defgh & $12,568 \mathrm{abc}$ \\
\hline HM PM21 & $2.40 \mathrm{~h}$ & 96.6 abcde & $17.12 \mathrm{abc}$ & $12,544 \mathrm{abc}$ \\
\hline Beta $4023 \mathrm{R}$ & $4.08 \mathrm{~cd}$ & 97.3 abcde & 16.73 defgh & $12,001 \mathrm{bcd}$ \\
\hline HM $2991 \mathrm{RZ}$ & $4.48 \mathrm{~b}$ & 88.3 fghi & $17.22 \mathrm{ab}$ & 11,761 bcde \\
\hline SX Puma & $2.60 \mathrm{~h}$ & 91.7 defgh & 16.78 cdefgh & $11,642 \mathrm{cdef}$ \\
\hline Crystal $333 \mathrm{R}$ & $3.67 \mathrm{ef}$ & 96.6 abcde & $16.32 \mathrm{ij}$ & $11,631 \mathrm{cdef}$ \\
\hline HH Acclaim R & $3.40 \mathrm{fg}$ & $97.5 \mathrm{abcd}$ & $16.24 \mathrm{j}$ & $11,622 \mathrm{cdef}$ \\
\hline HH Meridian R & $3.94 \mathrm{de}$ & 94.8 bcdef & $16.32 \mathrm{ij}$ & $11,441 \mathrm{def}$ \\
\hline HM 2984 RZ & $2.67 \mathrm{~h}$ & 92.6 cdefg & 16.45 hij & 11,416 def \\
\hline HM Owyhee & $2.54 \mathrm{~h}$ & 90.1 defghi & 16.76 defgh & $11,283 \mathrm{def}$ \\
\hline Beta $4773 \mathrm{R}$ & $4.27 \mathrm{bc}$ & 91.5 defghi & $16.39 \mathrm{ij}$ & $11,260 \mathrm{def}$ \\
\hline HM 2988 RZ & $4.11 \mathrm{~cd}$ & $83.4 \mathrm{ijk}$ & $17.21 \mathrm{ab}$ & 10,948 efg \\
\hline HM 2989 RZ & $4.13 \mathrm{~cd}$ & 84.7 hijk & $17.01 \mathrm{abcd}$ & 10,939 efg \\
\hline HM 2980 RZ & $4.51 \mathrm{~b}$ & $86.1 \mathrm{ghij}$ & 16.79 cdefg & 10,888 efg \\
\hline HH $142 \mathrm{R}$ & $4.05 \mathrm{~cd}$ & 89.2 efghi & $16.33 \mathrm{ij}$ & $10,864 \mathrm{efg}$ \\
\hline SX Raptor RZ & $4.36 \mathrm{bc}$ & 85.9 ghij & 16.56 fghij & $10,707 \mathrm{fgh}$ \\
\hline SX Mammoth RZ & $4.36 \mathrm{bc}$ & $77.3 \mathrm{kl}$ & $17.19 \mathrm{ab}$ & 10,044 ghi \\
\hline Crystal $217 \mathrm{R}$ & $4.27 \mathrm{bc}$ & $78.7 \mathrm{jkl}$ & 16.64 efghi & $9,756 \mathrm{hi}$ \\
\hline HH Eagle R & $5.20 \mathrm{a}$ & $76.9 \mathrm{kl}$ & 16.51 fghij & $9,697 \mathrm{i}$ \\
\hline HH Phoenix R & $5.27 \mathrm{a}$ & 72.21 & 16.46 ghij & $9,091 \mathrm{i}$ \\
\hline Overall mean & 3.78 & 91.4 & 16.76 & 11,533 \\
\hline Coefficient of variation & 8.3 & 8.8 & 2.1 & 8.5 \\
\hline$P>F^{\mathrm{z}}$ & $<0.0001$ & $<0.0001$ & $<0.0001$ & $<0.0001$ \\
\hline $\operatorname{LSD}(P \leq 0.05)$ & 0.31 & 7.8 & 0.34 & 970 \\
\hline
\end{tabular}

${ }^{y}$ Disease ratings were analyzed using the mean score for each plot (three ratings per plot). The disease index scale ranged from $0=$ no symptoms to $9=$ dead plant.

${ }^{\mathrm{z}} P>F$ was the probability associated with the $F$ value in the analysis of variance. LSD = Fisher's protected least significant difference. Means followed by the same letter within a column did not differ significantly based on Fisher's protected LSD with $P \leq 0.05$.

resistance and superior yields in commercial cultivars will be a challenge. Thus, we will need to rely on screening in curly top nurseries to select both resistant cultivars and superior germplasm in order to maintain or improve sugar beet resistance to curly top.

\section{ACKNOWLEDGMENTS}

These data support the objectives of the United States Department of Agriculture CRIS project 536821220-002-00D. We also wish to acknowledge the technical help of Terry Brown and Paul Foote.

\section{LITERATURE CITED}

1. Bartens, A. 2005. International Commission for Uniform Methods for Sugar Analysis Methods Book 2005. Dr. Albert Bartens KG, Berlin.

2. Bennett, C. W. 1971. The Curly Top Disease of Sugarbeet and Other Plants. Monogr. No. 7. American Phytopathological Society, St. Paul, MN.

3. Blickenstaff, C. C., and Traveller, D. 1979. Factors affecting curly top damage to sugarbeets and beans in southern Idaho, 1919-
77. Science and Education Administration, Agricultural Reviews and Manuals, Western Series, No. 8. U.S. Dep. Agric.-Agric. Res. Serv., Oakland, CA.

4. Bosemark, N. O. 1993. Genetics and breeding. Pages 66-199 in: The Sugar Beet Crop: Science Into Practice. D. A. Cooke, and R. K. Scott, eds. Chapman and Hall, London.

5. Camp, S., Foote, P., Strausbaugh, C. A., and Gillen, A. M. 2005. Evaluation of commercial sugar beet hybrids for resistance to beet curly top in Canyon County, ID, 2004. Biol. Cult. Tests Control Plant Dis. 20: FC023.

6. Creamer, R., Luque-Williams, M., and Howo, M. 1996. Epidemiology and incidence of beet curly top geminivirus in naturally infected weed hosts. Plant Dis. 80:533-535.

7. Duffus, J. E., and Skoyen, I. O. 1977. Relationship of age of plants and resistance to a severe isolate of the beet curly top virus. Phytopathology 67:151-154.

8. Gallian, J. J., and Stanger, C. E. 1993. Relationship of curly top disease ratings to yield loss under conditions of natural field infection. (Abstr.) J. Sugar Beet Res. 30:93.

9. Kaffka, S. R., Wintermantel, W. M., and Lewellen, R. T. 2002. Comparisons of soil and seed applied systemic insecticides to control beet curly top virus in the San Joaquin Valley. J. Sugar Beet Res. 39:59-74.

10. Mumford, D. L. 1974. Procedure for inducing curly top epidemics in field plots. J. Am. Soc. Sugar Beet Technol. 18:20-23.

11. Mumford, D. L., and Griffin, G. D. 1973 Evaluation of systemic pesticides in controlling sugarbeet leafhopper. J. Am. Soc. Sugar Beet Technol. 17:354-357.

12. Ritenour, G., Hills, F. J., and Lange, W. H. 1970. Effect of planting date and vector control on the suppression of curly top and yellows in sugarbeet. J. Am. Soc. Sugar Beet Technol. 16:78-84.

13. Shock, C. C., Eldredge, E. P., and Saunders, L. D. 2006. Sugar beet variety trials 2005. Pages 210-216 in: Malheur Experiment Station Annual Report 2005, Oregon State University Agricultural Experiment Station, Special Report 1070, Corvallis, OR.

14. Stenger, D. C. 1998. Replication specificity elements of the Worland strain of beet curly top virus are compatible with those of the $\mathrm{CFH}$ strain but not those of the Cal/Logan strain Phytopathology 88:1174-1178.

15. Stenger, D. C., Carbonaro, D., and Duffus, J. E. 1990. Genomic characterization of phenotypic variants of beet curly top virus. J. Gen. Virol. 71:2211-2215.

16. Stenger, D. C., Davis, K. R., and Bisaro, D. M. 1994. Recombinant beet curly top virus genomes exhibit both parental and novel pathogenic phenotypes. Virology 200:677-685.

17. Stenger, D. C., and McMahon, C. L. 1997. Genotypic diversity of beet curly top virus populations in the western United States. Phytopathology 87:737-744.

18. Stenger, D. C., and Ostrow, K. M. 1996. Genetic complexity of a beet curly top virus population used to assess sugar beet cultivar response to infection. Phytopathology 86:929933.

19. Strausbaugh, C. A., Gillen, A. M., Gallian, J. J., Camp, S., and Stander, J. R. 2006. Influence of host resistance and insecticide seed treatments on curly top in sugar beets. Plant Dis. 90:1539-1544.

20. Strausbaugh, C. A., Gillen, A. M., Shock, C. C., and Eldredge, E. P. 2006. Evaluation of commercial sugar beet hybrids for resistance to beet curly top in Malheur County, OR, 2005. Biol. Cult. Tests Control Plant Dis. 21:FC039.

21. Sunter, G., Sunter, J. L., and Bisaro, D. M. 2001. Plants expressing Tomato golden mosaic virus $A L 2$ or Beet curly top virus $L 2$ transgenes show enhanced susceptibility to infection by DNA and RNA viruses. Virology 285:59-70.

22. Swiech, R., Browning, S., Molsen, D., Stenger, D. R., and Holbrook, G. P. 2001. Photosynthetic responses of sugarbeet and Nicotiana benthamiana Domin. infected with beet curly top virus. Physiol. Mol. Plant Pathol. 58:43-52

23. Wang, H., Gurusinghe, P. de A., and Falk, B. W. 1999. Systemic insecticides and plant age affect beet curly top virus transmission to selected host plants. Plant Dis. 83:351-355.

24. Wintermantel, W. M., and Kaffka, S. R. 2006. Sugar beet performance with curly top is related to virus accumulation and age at infection. Plant Dis. 90:657-662. 